\title{
OCENA LOGISTYCZNEJ OBSLUGI KLIENTA ORAZ OFERTY ASORTYMENTOWEJ HANDLU ELEKTRONICZNEGO
}

\section{Wstęp}

Handel internetowy w Polsce odgrywa coraz większą rolę w zaopatrzeniu ludności. Z roku na rok rośnie skłonność do zakupu produktów, które nie były dotychczas traktowane przez wielu konsumentów jako „,internetowe”, np. produkty spożywcze. Na dotychczasowy rozwój e-commerce w Polsce nie miał większego wpływu kryzys finansowy ${ }^{1}$.W wyniku tego zaobserwować można gwałtowny wzrost liczby polskich sklepów internetowych, których w 2013 r. może być już nawet 16 tys. $^{2}$

Internet jest najbardziej dynamicznie rozwijającym się kanałem dystrybucji polskiego handlu. Na tak szybki rozwój wartości sprzedaży w Internecie i rosnącą liczbę e-sklepów największy wpływ ma niewątpliwie coraz większe przekonanie Polaków do kupowania w sieci. Klienci dostrzegają ogromne możliwości e-handlu, a z drugiej strony e-sklepy dostosowują się szybko do wymagań klientów, by sprostać ich oczekiwaniom. By zapewnić jak największy komfort zakupów, sprzedawcy oferują możliwość wyboru sposobu zapłaty, rodzaju przesyłki czy też podgląd stanu magazynowego. Implikuje to konieczność dostrzeżenia logistycznej obsługi klienta jako instrumentu tworzenia przewagi konkurencyjnej.

Celem artykułu jest analiza procesu przepływu towarów oferowanych za pośrednictwem wirtualnych łańcuchów dostaw. Szczególną uwagę zwrócono na charakterystykę produktów sprzedawanych $\mathrm{w}$ Internecie oraz preferencje e-klientów. Starano się również odpowiedzieć na pytanie, czy towary dostępne w wirtualnych sklepach można traktować jako produkty logistyczne, których przepływ w kanałach dystrybucji jest podporządkowany zasadom logistycznej obsługi klienta.

Zagadnienia teoretyczne wsparte zostały wynikami badań empirycznych przeprowadzonych wśród sklepów internetowych oraz internautów dokonujących zakupów w sieci. Celem badań było porównanie oczekiwań klientów co

\footnotetext{
* Doktorantka, Katedra Marketingu, Wydział Zarządzania UŁ.

${ }^{1} \mathrm{http}: / /$ www.pmrpublications.com/product/Handel-internetowy-w-Polsce-2012 (dostęp 08.05.2013.

${ }^{2}$ A. Jadczak, eCommerce 2012, Internet Standard, s. 32, http://www.internetstandard.pl/news/ event/15/946567/1B8885129EFD40F193C576EBEC22236C (dostęp 29.04.2013).
} 
do asortymentu oraz poziomu obsługi w e-sklepie i skonfrontowanie ich $\mathrm{z}$ opinią i ofertą sprzedających.

Badania zostały zrealizowane za pośrednictwem portalu ankietowego mojeankiety.pl w okresie od 25 stycznia 2013 do 6 marca 2013 r. i wzięło w nich udział 419 respondentów z których jakichkolwiek zakupów za pośrednictwem Internetu dokonało 354 pytanych, tj. 84,5\% badanych.

Ankieta miała charakter publiczny, a zaproszenia do badania rozesłano za pośrednictwem poczty elektronicznej oraz umieszczono na portalach społecznościowych nk.pl oraz facebook.com. Badana próba ma charakter przypadkowy a wyniki zbierano z wykorzystaniem metody kuli śnieżnej, gdyż każdy respondent został poproszony o dalsze udostępnianie zaproszenia do badania. Równolegle przeprowadzone zostały badania ankietowe dotyczące logistycznych aspektów handlu elektronicznego, w których wzięło udział 129 e-sklepów. Dobór próby także miał charakter przypadkowy, a zaproszenie do wypełnienia ankiety rozesłano pocztą e-mail do 2320 sklepów.

\section{Istota produktu logistycznego}

Produkt logistyczny jest zbiorem życzeń i oczekiwań klienta wobec towarów lub usług co do ich postaci i jakości, których przepływ realizowany jest w systemie logistycznym. W związku z tym towar lub usługa jako produkty logistyczne są z jednej strony produktami przepływu, z drugiej umożliwiają osiągnięcie zysków wszystkim uczestnikom kanału ${ }^{3}$.

Produkt logistyczny charakteryzuje się złożoną strukturą wewnętrzną (rysunek 1), w której E. Gołembska wyróżnia trzy poziomy:

- pierwszy dotyczy fizycznej postaci produktu, jego istoty w postaci cech fizykochemicznych i właściwości;

- drugi poziom to towar jako ładunek, mający określoną wagę, kształt i opakowanie, a przede wszystkim markę;

- trzeci poziom to produkt logistyczny zgodny z przedstawioną wcześniej definicją, obejmujący zbiór życzeń i oczekiwań odbiorców, oznaczający przemieszczanie i magazynowanie ładunku wraz z czynnościami dodatkowymi, jak ubezpieczenie ${ }^{4}$.

Produkt logistyczny, jak i każdy inny, charakteryzuje się cyklem życia, na który poza wahaniami popytu i podaży wpływają takie czynniki, jak: charakter zachowań i stopień zaspokojenia użytkowników całego systemu logistycznego, zachowanie konkurencji i stopień substytucyjności.

${ }^{3}$ E. Gołembska (red.), Kompendium wiedzy o logistyce, Wydawnictwo Naukowe PWN, Warszawa 2007, s. 53.

${ }^{4}$ Ibidem, s. 57. 


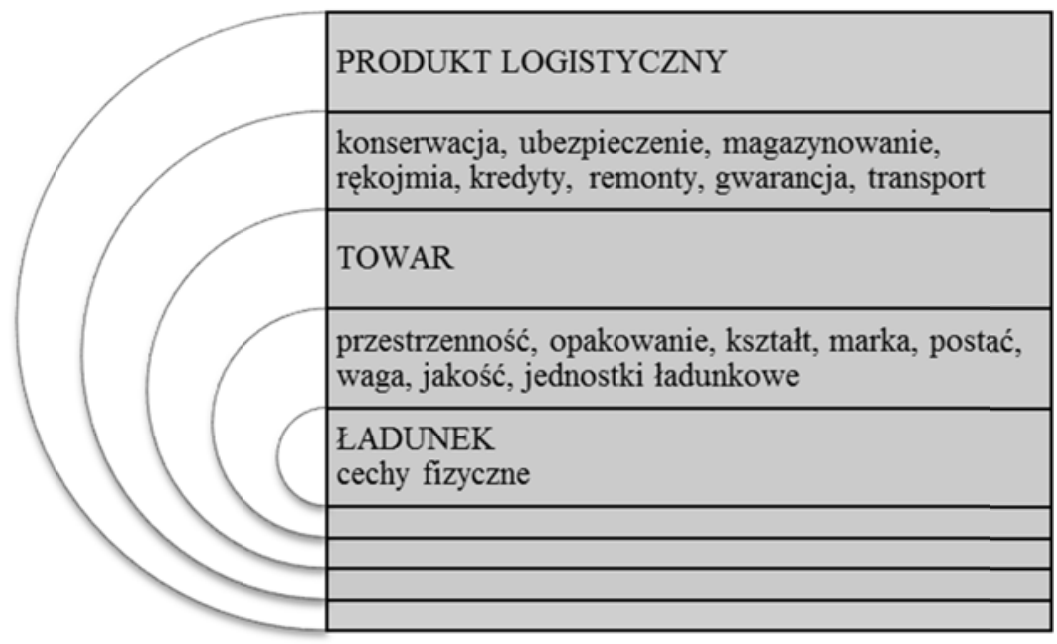

Rysunek 1. Struktura produktu logistycznego

Źródło: opracowanie własne na podstawie: E. Gołembska (red.), Kompendium wiedzy o logistyce, Wydawnictwo Naukowe PWN, Warszawa 2007, s. 58.

Substytucyjność produktu logistycznego rozumiana jest w szerszymm wymiarze niż tylko zdolność do zastąpienia jednego produktu drugim o podobnych czy wręcz identycznych właściwościach, jakości i cenie. Produkt logistyczny określa się jako wysoce substytucyjny, gdy jego odbiorca znajduje niewielkie różnice w cenie i jakości dóbr, przy braku dostępności dotychczas nabywanego, dlatego w dystrybucji celem strategicznym jest zwiększenie jego dostępności dla konsumentów, aby nie rozważali zakupu produktu substytucyjnego 5 .

\section{Produkt $w$ handlu elektronicznym jako produkt logistyczny}

Zadaniem logistyki jest dostarczenie odpowiedniego produktu klientowi. W odniesieniu do zakupów internetowych gra ona rolę nadrzędną, gdyż warunki i szybkość dostawy są wartością dodaną do produktu, często mającą decydujący wpływ na decyzje zakupowe. W tym kontekście należy się zastanowić, czy produkty sprzedawane za pośrednictwem internetowych kanałów dystrybucji można nazwać produktami logistycznymi i traktować je tak samo jak towary w tradycyjnych przepływach.

Zasadniczo wyróżnia się dwa rodzaje produktów dostępnych w Internecie: produkty tradycyjne i produkty internetowe, jednak w nowoczesnej gospodarce

\footnotetext{
${ }^{5}$ Ibidem, s. 59.
} 
oba typy produktów zaczynają się wzajemnie przenikać, tworząc trzeci typ - produkt mieszany.

Przykładem produktu czysto ,internetowego" może być program komputerowy napisany i dystrybuowany wyłącznie w sieci lub grafika wystawiona do sprzedaży na stronie internetowej ${ }^{6}$. Nasuwa się tu pytanie, czy produkt mający formę wyłącznie elektroniczną można nazwać produktem logistycznym?

Produkty elektroniczne nie mają fizycznej postaci, w związku z tym nie posiadają kształtu czy przestrzenności oraz nie wymagają opakowania. Rynek wirtualny jest naturalnym środowiskiem sprzedaży produktów informacyjnych, czyli plików, które można zapisać w formie bitów, np. elektronicznych książek, bazy danych, pism, filmów, portali informacyjnych. Bity wyrażają elektroniczną wielkość pliku, którą można porównać do wagi tradycyjnego produktu. Produkty te mogą być dostarczane bezpośrednio i natychmiast przez Internet użytkownikom, bez konieczności fizycznego ich transportu? ${ }^{7}$. Jednak, by dostarczyć produkt do konsumenta, potrzebna jest infrastruktura informatyczna w postaci łącza internetowego, za pomocą którego dostawa się odbywa. Ponadto sprzedawcy potrzebny jest swego rodzaju „magazyn” plików, jakim jest serwer internetowy. Produkty elektroniczne objęte są gwarancją czy rękojmią oraz podlegają swego rodzaju konserwacjom czy remontom w postaci np. aktualizacji programu do nowszej wersji. W związku z tym można stwierdzić, że towary elektroniczne noszą znamiona produktów logistycznych i powinny być tak samo traktowane jak produkty ,fizyczne”.

Produktem tradycyjnym jest dobro istniejące w realnej rzeczywistości, dostępne także bez pośrednictwa Internetu w tradycyjnym sklepie. Są to wszelkie produkty materialne, zaczynając od dostępnych już w Internecie produktów żywnościowych poprzez książki, kosmetyki i ubrania, kończąc na sprzęcie AGD/RTV. Produkty te posiadają wszystkie cechy fizyczne, aby móc je nazwać towarem logistycznym. Towary te magazynowane są przez sprzedawców lub producentów i dystrybutorów w zależności od tego, czy sklep internetowy działa samodzielnie, czy też jedynie jako pośrednik w systemie dropshippingu ${ }^{8}$. Po dokonaniu zakupu przez klienta towar jest dostarczany najczęściej przez firmę logistyczną w odpowiednim opakowaniu zapobiegającym jego uszkodze-

${ }^{6}$ T. Maciejowski, Firma w Internecie, Oficyna Ekonomiczna, Kraków 2004, s. 160.

${ }^{7}$ C. Shapiro, H. R. Varian, Potega informacji. Strategiczny przewodnik po gospodarce sieciowej, Harvard Business School Press 2007, s. 69-73.

${ }^{8}$ Dropshipping - model logistyczny sprzedaży przez internet, polegający na przeniesieniu procesu wysyłki towaru na dostawcę. Rola sklepu internetowego w tym modelu logistycznym sprowadza się do zbierania zamówień i przesyłanie ich do dostawcy, który realizuje wysyłkę towaru do klienta. G. Chodak, Dropshipping - model logistyczny dla sklepu internetowego, [w:] S. Lachiewicz, A. Zakrzewska-Bielawska (red.), Teoria i praktyka zarządzania rozwojem organizacji, Wydawnictwo PŁ, Łódź 2008, s. 248-255 
niu i ubezpieczony przynajmniej na czas transportu. Płatność za towar odbywa się obecnie głównie za pośrednictwem e-przelewu lub gotówką przy odbiorze. Jednak nie są to wszystkie możliwe formy uiszczenia opłaty za zakup w Internecie. Współcześnie można dokonać zakupów w sieci również na kredyt bez wychodzenia $\mathrm{z}$ domu.

Zarówno produkty stricte elektroniczne, jak i te tradycyjne posiadają cechy produktów logistycznych, w związku z tym ich przepływ w całym kanale logistycznym powinien być podporządkowany nadrzędnej zasadzie logistyki zawierającej się w skrócie $7 \mathrm{~W}^{9}$.

W handlu elektronicznym, gdzie klient ma możliwość odwiedzenia wielu sklepów naraz i porównania oferty, mamy do czynienia z wysokim stopniem substytucyjności produktów, która wyrażana jest u sprzedającego w utraconej możliwości sprzedaży. Janusz Wielki stwierdza, że najważniejszym wyróżnikiem produktów dostępnych $\mathrm{w}$ Internecie jest możliwość ich informacyjnego nasycenia ${ }^{10}$. Internet posiada wręcz nieograniczoną, dzięki której dostawcy towarów i usług mogą do woli mnożyć informacje na swoich stronach internetowych, umieszczając tam opisy produktów, zdjęcia, filmy, instrukcje montażu i użytkowania, opinie innych użytkowników i specjalistów ${ }^{11}$.

Zabiegi takie mają na celu przyciągnięcie klientów do sklepu, zachęcenie do powtórnych zakupów i w efekcie wzbudzenie lojalności, co jest niezwykle trudne w handlu elektronicznym. Klient, mając możliwość zakupu w sieci tego samego produktu w co najmniej kilkunastu sklepach, wybierze ten, w którym zapłaci najmniej. Warto tu zwrócić uwagę, że nie jest ważna cena samego produktu, ale koszty ogólne ponoszone przez konsumenta w związku z zakupem, na które obok ceny towary składają się koszty dostawy. Jak wykazały badania, koszt dostawy jest dla internautów najistotniejszym kryterium decyzyjnym przy dokonywaniu e-zakupów.

Ponadto nasycenie informacyjne produktów na wirtualnym rynku powoduje, że obsługa transportowa może prowadzić do zmniejszenia kosztu utraconej sprzedaży, ponieważ poprzez szybkość i niezawodność dostaw oraz zmniejszenie strat $\mathrm{i}$ ubytków towar staje się bardziej dostępny dla odbiorcy, w wyniku czego maleją koszty obsługi logistycznej.

${ }^{9}$ Zasada $7 \mathrm{~W}$ definiuje siedem wymogów postępowania w procesie przepływu materiałów oraz odpowiednią realizację podstawowych zadań logistyki w przedsiębiorstwie i jest thumaczeniem z języka angielskiego zasady 7R $(\mathrm{R}-$ right). Oznacza: Właściwy produkt - Right product, Właściwa ilość - Right quantity, Właściwy stan - Right condition, Właściwe miejsce - Right place, Właściwy czas - Right time, Właściwy konsument (klient) - Right customer, Właściwy koszt (cena) - Right price.

${ }^{10}$ J. Wielki, Elektroniczny marketing poprzez Internet, Wydawnictwo Naukowe PWN, Warszawa-Wrocław 2000, s. 105.

${ }^{11}$ T. Maciejowski, Firma..., s. 162. 


\section{Przepływ towarów w e-lańcuchu dostaw}

Nie ulega wątpliwości, że Internet wywiera ogromny wpływ na poziom konkurencji pomiędzy handlem tradycyjnym a wygodnym i szybkim handlem internetowym. W polskich e-sklepach zakupić można już niemal wszystko, co jest niewątpliwie zauważane przez e-klientów i doceniane (rysunek 2). Z badań własnych wynika, że co piąty respondent uważa, iż asortyment produktów w polskich sklepach elektronicznych jest bardzo szeroki. $43 \%$ ocenia go jako szeroki, natomiast blisko co trzeci pytany uważa, że oferta asortymentowa jest wystarczająca. Za niezadowolonych $\mathrm{z}$ szerokości asortymentu $\mathrm{w}$ sieci można uznać 5\% pytanych, według których oferta produktowa dostępna w sieci jest wąska.

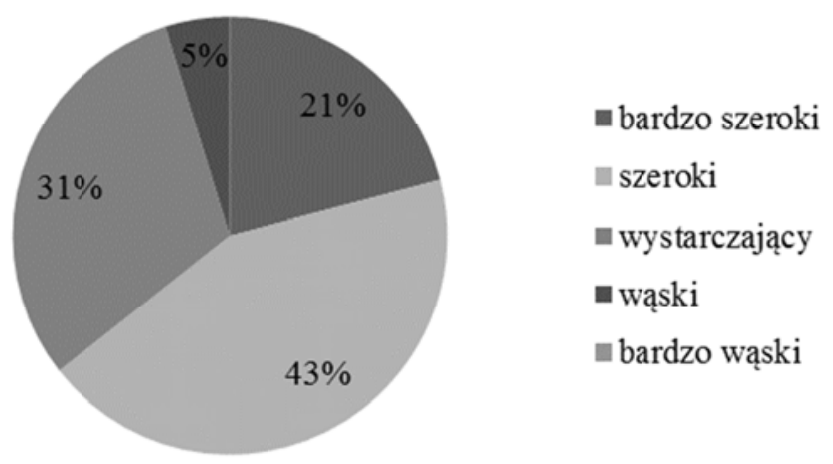

Rysunek 2. Ocena asortymentu towarowego dostępnego w polskich sklepach internetowych (w \%) Źródło: Badania własne.

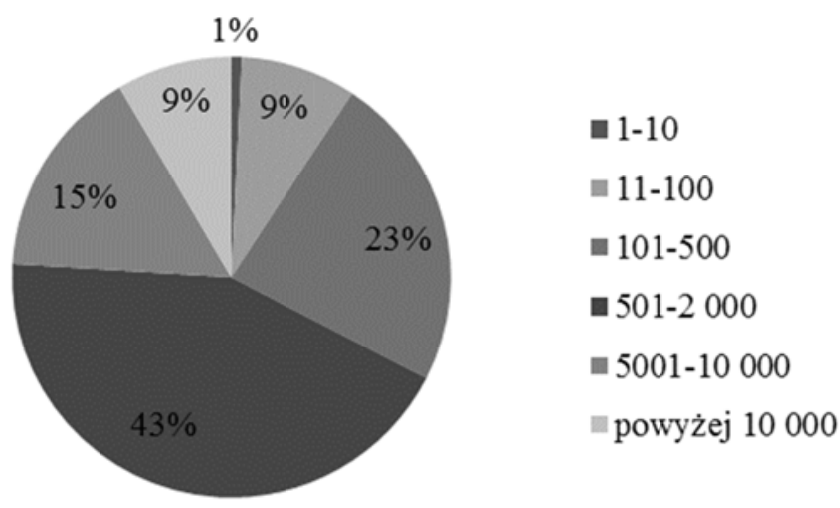

Rysunek 3. Wielkość asortymentu w polskich sklepach elektronicznych (w \%) Źródło: Badania własne. 
Dbając o zadowolenie klienta i mając na uwadze substytucyjnošć produktów w sieci, e-sklepy starają się oferować szeroki wachlarz produktów współpracując tym samym z wieloma dostawcami. $43 \%$ sklepów ma w ofercie od 500 do 2000 produktów, $23 \%$ od 100 do 500 , co 10 . sklep oferuje do 100 produktów. Nawet 10000 produktów posiada w asortymencie $15 \%$ pytanych, a $9 \%$ może pochwalić się asortymentem powyżej 10000 unikatowych towarów (rysunek 3).

E-sklepy zaopatrują się zarówno na rynku krajowym (89\%), jak i importują towary z zagranicy (64\%). 98\% powtarza zakupy u tych samych dostawców, a jako powody najczęściej wymieniają solidność dostawcy (77\%), atrakcyjne ceny zakupywanych produktów $(68 \%)$, terminowość dostaw $(57 \%)$ oraz zawarte umowy i kontrakty (47\%). Co trzeci sklep współpracuje ze swoim kluczowym dostawcą od ponad 6 lat, tyle samo e-sklepów zaznaczyło odpowiedź 3-6 lat.

Zarządzanie tak szerokim asortymentem wymaga logistycznego podejścia do organizacji sprzedaży, częstych dostaw towaru oraz w przypadku działalności na własny rachunek - magazynu. Blisko 9 na 10 sklepów handlujących w Internecie posiada własny magazyn o wielkości do $100 \mathrm{~m}^{2}$. Dostępność towaru jest w logistyce aspektem najważniejszym, klient bowiem ma otrzymać produkt logistyczny dokładnie wtedy, gdy go potrzebuje, co wymusza na e-sprzedających częste uzupełnianie asortymentu. Badania wykazały (rysunek 4), że co piąty sklep uzupełnia swoje magazyny codziennie, natomiast co trzeci kilka razy $\mathrm{w}$ tygodniu. Raz w tygodniu asortyment uzupełnia $16 \%$ ankietowanych, a $22 \%$ z nich zaopatruje się raz bądź kilka razy w miesiącu.

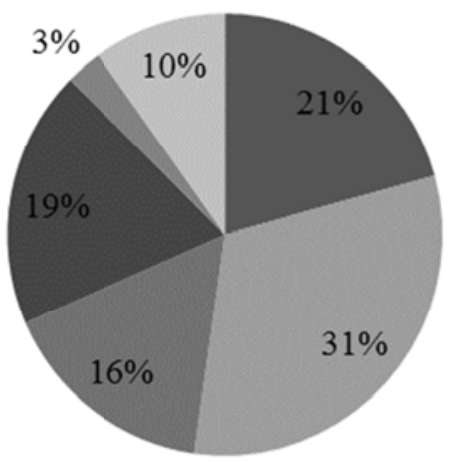

a Codziennie

Kilka razy w tygodniu

naz w tygodniu

Kilka razy w miesiącu

naz w miesiącu

Rysunek 4. Częstotliwość uzupełniania asortymentu przez polskie e-sklepy (w \%) Źródło: Badania własne.

Zaopatrzenie sklepu to pierwszy krok prowadzenia e-handlu. Kolejnym jest jego udostępnienie. Elektronicznym kanałem sprzedaży jest strona internetowa sklepu, pasaż internetowy, katalog, serwis ogłoszeniowy i wreszcie najpopularniejsze w Polsce - portale aukcyjne, za pośrednictwem których handluje 7 na 
10 sklepów. Niekwestionowanych liderem e-zakupów jest Allegro.pl, na którym sprzedaje $95 \%$ wirtualnych sklepów, powszechne stało się bowiem korzystanie z kilku kanałów sprzedaży równocześnie.

Mimo ogromnego wyboru i dostępności produktów w Internecie nie udaje się zwirtualizować sprzedaży niektórych produktów. Na rynku wirtualnym brak jest możliwości świadczenia usług powstających w bezpośrednim kontakcie z nabywcą lub jego rzeczami i mających bezpośredni efekt, np. fryzjerskich, prania chemicznego ${ }^{12}$. Przykładami innych produktów, których dystrybucja napotyka na trudności w Internecie, $\mathrm{sac}^{13}$ :

- towary delikatne, które mogą ulec uszkodzeniu w czasie dostawy;

- towary wymagające fizycznego oglądu ze względu na ich jakość, kolor, zapach, wrażenia dotykowe itp.;

- towary nietrwałe, łatwo psujące się;

- towary o wysokiej cenie, $\mathrm{z}$ wyjątkiem zestandaryzowanych produktów, których jakości konsument może być pewien.

Polscy e-klienci nie kupowaliby w sieci odzieży (32\%) oraz żywności (31\%) (rysunek 5), zwierząt, sprzętu RTV/AGD oraz kosmetyków i leków, które wymieniło kolejno 7 i $6 \%$ pytanych.
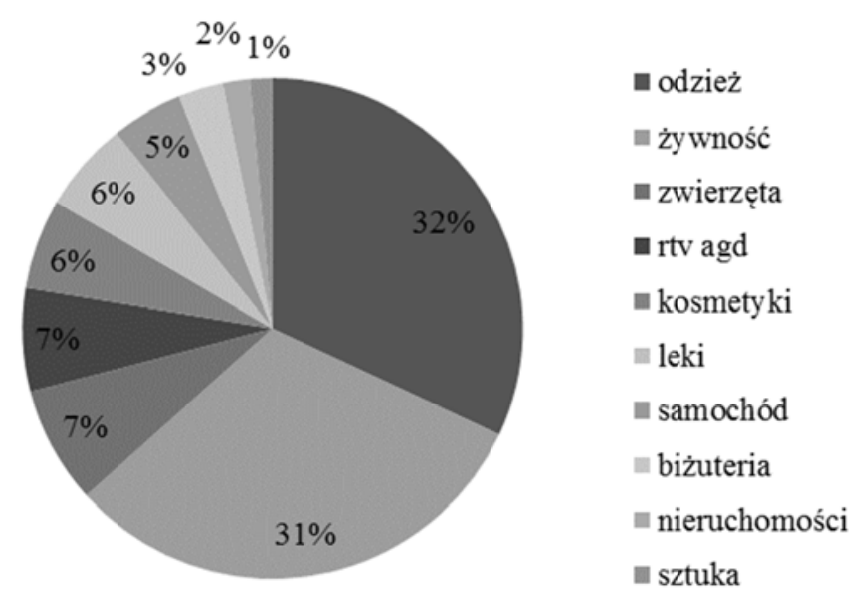

Rysunek 5. Produkty, których e-klienci nie kupowaliby w Internecie (w \%) Źródło: Badania własne.

${ }^{12}$ U. Świerczyńska-Kaczor, P. Kossecki,Wirtu@lny rynek. Inwestorzy. Przedsiębiorstwa. Klienci, Wydawnictwo Uniwersytetu Humanistyczno-Przyrodniczego Jana Kochanowskiego, Kielce 2008, s. 93.

${ }^{13}$ P. Bickerton, M. Bickerton, U. Pardesi, Marketing w Internecie, Gdańskie Wydawnictwo Psychologiczne, Gdańsk 2006, s. 209-210. 
Na trudności w sprzedaży internetowej napotykają te produkty, które konsument kupuje, opierając się na wrażeniach dotykowych oraz w przypadku większości towarów luksusowych. W sytuacji ich sprzedaży klient potrzebuje emocjonalnej więzi z wybranym towarem, a także satysfakcji związanej z dokonaniem zakupu i warunków, w jakich tego dokona1 ${ }^{14}$. $\mathrm{Z}$ badań wynika, że dla co trzeciego kupującego w Internecie internauty fizyczny kontakt z produktem ma znaczenie, dla $56 \%$ jest to uzależnione od rodzaju towaru, a dla $13 \%$ nie ma znaczenia (rysunek 6).

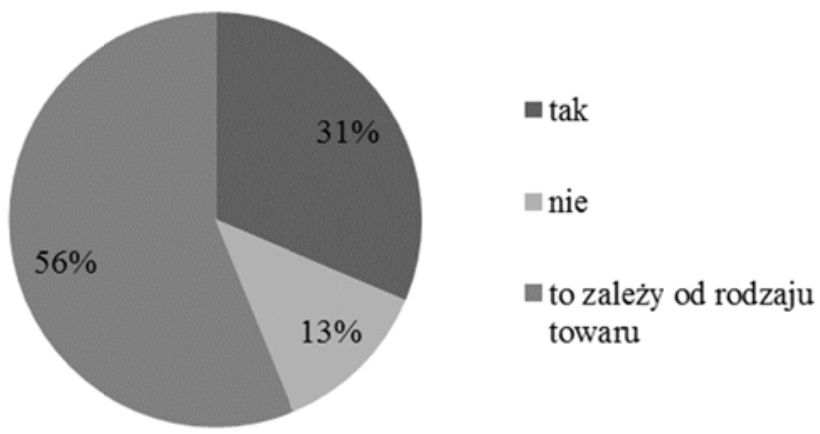

Rysunek 6. Znaczenie fizycznego kontaktu z kupowanym produktem w handlu elektronicznym (w \%) Źródło: Badania własne.

Po dokonaniu zakupu za pośrednictwem Internetu produkt trafia do konsumenta. Jednak nie zawsze spełnia on jego wymagania, co wynika z braku możliwości fizycznego kontaktu $\mathrm{z}$ towarem i jego oceny, jak również może być skutkiem uszkodzenia podczas transportu. Przy projektowaniu kompletnego systemu logistyki dla e-handlu trzeba uwzględnić przepływy produktów w obie strony, czyli ująć logistykę zwrotną, elementem produktu logistycznego bowiem jest gwarancja, rękojmia, ubezpieczenie towaru.

\section{Logistyka zwrotna}

Logistyka zwrotna stanowi stosunkowo nowy obszar badawczy zarówno w warstwie teoretycznej, jak i empirycznej. W literaturze anglojęzycznej można spotkać takie pojęcia, jak dystrybucja odwrotna (reverse distribution), logistyka zwrotów (return logistics), odwrócona logistyka (reversed logistics) czy logistyka działająca wstecz (retro logistics), które w istocie są synonimami ${ }^{15}$.

\footnotetext{
${ }^{14}$ U. Świerczyńska- Kaczor, P. Kossecki, Wirtu@lny rynek..., s. 93.

${ }^{15}$ A. Sadowski, Zarys rozwoju logistyki zwrotnej, „Logistyka” 2009, nr 5, s. 12.
} 
Logistyka zwrotna w sposób zasadniczy różni się od takich dziedzin, jak zarządzanie odpadami, które odnosi się głównie do skutecznego i efektywnego zbierania oraz przetwarzania odpadów. W zarządzaniu odpadami przyjmuje się, że pojęcie odpadów określa produkty, dla których nie istnieje nowe zastosowanie. Wypływa stąd wniosek, iż problemy z uściśleniem koncepcji logistyki zwrotnej oraz jej rozgraniczeniem w stosunku do innych, pokrewnych dziedzin nauki sprowadzają się do rozumienia pojęcia „odpady" wraz ze wszystkimi wynikającymi z definicji konsekwencjami. Logistyka zwrotna dotyczy takich strumieni przepływów, w których istnieje możliwość odtworzenia wartości z wycofywanych produktów oraz sytuacji, gdy wyjście stanowi zasilenie dla nowego łańcucha dostaw ${ }^{16}$.

Produktami logistyki zwrotnej są:

- produkty uszkodzone,

- produkty błędnie dostarczone,

- produkty zużyte,

- produkty zbędne,

- opakowania,

- odpady.

W handlu elektronicznym można wyróżnić następujące obszary logistyki zwrotnej:

- zwroty produktów ni uszkodzonych,

- reklamacje i gwarancje,

- utylizacja zużytego sprzętu,

- gospodarka opakowaniami.

Logistyka zwrotna jest elementem obsługi posprzedażnej klienta. Kanały dystrybucji elektronicznej muszą być dostosowane do obsługi zwrotów i reklamacji od pojedynczych klientów. Wiele sklepów „,pomija” ten obszar działania firmy. Badania przeprowadzone w 1999 r. przez Federalną Komisję Handlu Stanów Zjednoczonych wskazały, że zaledwie $26 \%$ firm biorących udział w sondażu zamieściło na swoich witrynach informacje o możliwości zwrotu pieniędzy, a jedynie $9 \%$ sklepów opublikowało warunki odwołania ${ }^{17}$. W sytuacji, gdy klient dokonuje zwrotu zakupionego towaru, istotne są dwa aspekty: zagwarantowanie samego prawa zwrotu oraz zapewnienie odpowiedniej logistyki umożliwiającej jego dokonanie ${ }^{18}$.

Gwarancji i rękojmi mogą udzielać zarówno dostawcy internetowi oraz strony trzecie. W przypadku umożliwienia korzystania z gwarancji i reklamowania wadliwych produktów najważniejszy jest czas reakcji i wygoda dla

\footnotetext{
${ }^{16}$ Ibidem.

${ }^{17}$ P. Bickerton, M. Bickerton, U. Pardesi, Marketing..., s. 176.

${ }^{18}$ U. Świerczyńska-Kaczor, P. Kossecki, Wirtu@lny rynek..., s. 107.
} 
kupującego. Jeśli nie jest możliwe oddanie towaru czy jego naprawienie za pośrednictwem Internetu (tak jak to ma miejsce w przypadku choćby programów komputerowych), to ważnym elementem jest posiadanie odpowiedniego zaplecza zapewniającego serwis czy możliwość zwrotu towaru. Takie zaplecze posiadają firmy prowadzące działalność także za pomocą tradycyjnych kanałów dystrybucji. Klient np. może oddać wadliwy towar do najbliższego sklepu danej sieci. Rozwiązanie to ogranicza koszty klienta związane z samym odsyłaniem produktu, np. pocztą kurierską ${ }^{19}$.

Odsetek zwrotów zakupów on-line różni się w zależności od branży i rodzaju dóbr, ale $\mathrm{z}$ reguły jest od 50 do $100 \%$ wyższy w porównaniu $\mathrm{z}$ tradycyjnym handlem. 94\% wirtualnych sklepów obserwuje wielkość zwrotów nie przekraczającą poziomu $10 \%$ wszystkich zamówień, $4 \%$ zanotowało wyższy wskaźnik zwrotów dochodzący nawet do $30 \% .2 \%$ ankietowanych sklepów nie przyjmuje zwrotów (rysunek 7).

Sprzedawcy internetowi, aby zachęcić klientów do robienia zakupów w sieci i zapewnić wysoki poziom obsługi, wprowadzili liberalną politykę zwrotów, gwarantując możliwość oddania zakupionego towaru bez względu na powód rezygnacji z zakupionego produktu.

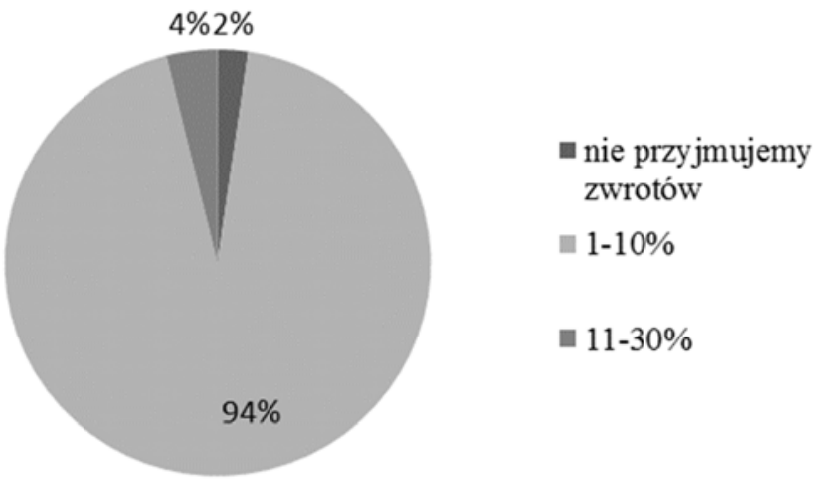

Rysunek 7. Odsetek zamówień stanowiących zwroty w polskich sklepach elektronicznych (w \%) Źródło: Badania własne.

Do najczęstszych przyczyn zwrotu towarów kupionych w internecie należą: wady produktów i ich uszkodzenia, niezgodność co do ilości lub rodzaju otrzymanych produktów z zamówieniem, zwroty niesprawnych urządzeń ma gwarancji, niespełnienie oczekiwań klienta ${ }^{20}$. W przypadku zakupu odzieży obserwuje

${ }^{19}$ Ibidem.

${ }^{20}$ K. Rutkowski, Logistyka dystrybucji. Specyfika. Tendencje rozwojowe. Dobre praktyki, SGH, Warszawa 2005, s. 29. 
się rosnącą tendencję do stosowania tego typu praktyk. Klienci zamawiają określoną rzecz w kilku rozmiarach, a po przymierzeniu zwracają niepasujące ${ }^{21}$.

$\mathrm{Z}$ badań wynika, że w blisko 9 na 10 sklepów uszkodzenie i wada towaru stanowią jedynie do 10\% wszystkich zwrotów (rysunek 8).

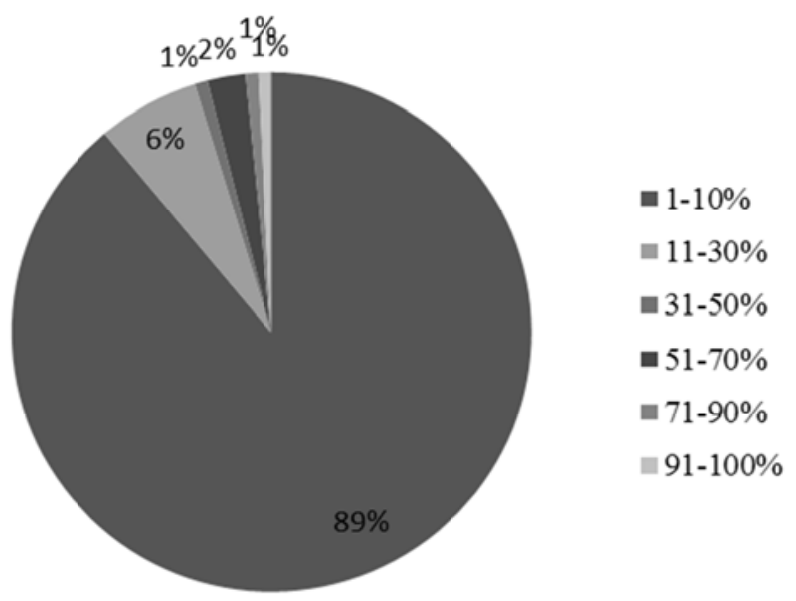

Rysunek 8. Procent wszystkich zwrotów stanowiący reklamacje wynikające z wady towaru (w \%) Źródło: badania własne.

W przypadku zakupu towaru przez Internet na podstawie ustawy z 2 marca 2000 r. o ochronie niektórych praw konsumentów oraz o odpowiedzialności za szkodę wyrządzoną przez produkt niebezpieczny mamy prawo do zwrotu towaru bez podania jakiejkolwiek przyczyny w okresie do 10 dni od otrzymania towaru, a w przypadku, kiedy sprzedawca nas nie poinformował o tym prawie, to czas jego obowiązywania wydłuża się nawet do 3 miesięcy ${ }^{22}$.

Należy jednak pamiętać, iż w przypadku zwrotu towaru to klient ponosi koszty jego odesłania, a zwrotowi podlega tylko kwota równa wartości towaru, czyli klient jest stratny o dwukrotne koszty przesyłki.

W przypadku uszkodzeń wynikających ze złego transportu towaru i widocznym uszkodzeniu przesyłki należy otworzyć paczkę w obecności listonosza (kuriera) i poprosić o odpowiednią adnotację o uszkodzeniu opakowania (nawet, gdy towar nie wydaje się być uszkodzony $)^{23}$.

W przypadku ujawnienia się wady możemy wedle swego uznania skorzystać bądź to z gwarancji producenta (o ile taka była udzielona i nie minął okres

${ }^{21}$ Ibidem.

${ }^{22}$ Ustawa z dnia 2 marca 2000 r. o ochronie niektórych praw konsumentów oraz o odpowiedzialności za szkodę wyrządzoną przez produkt niebezpieczny, http://isip.sejm.gov.pl/servlet/ Search?todo=file\&id=WDU20000220271 \&type=3\&name=D20000271Lj.pdf (dostęp 14.09.2011).

${ }^{23}$ R. Barcik, Logistyka dystrybucji, Wydawnictwo ATH, Bielsko-Biała 2005, s. 330. 
gwarancyjny), bądź z instytucji niezgodności towaru z umową na podstawie ustawy z 27 lipca 2002 r. o szczególnych warunkach sprzedaży konsumenckiej oraz o zmianie Kodeksu cywilnego ${ }^{24}$.

Menedżerowie e-sklepów nie mogą ignorować problemu, jakim są zwroty, a politykę i system zwrotów powinni opracować w momencie tworzenia strategii dystrybucji. Dla e-sprzedaży obsługa zwrotów stanowi dużo większy problem niż dla tradycyjnego biznesu, ponieważ trzeba wyznaczyć i zorganizować efektywne procedury odbioru pojedynczych dóbr od konsumentów, a trudno jest określić zapotrzebowanie na te usługi pod względem ilości, jakości oddawanych dóbr, a co za tym idzie nie można jednoznacznie zaplanować obciążenia tras powrotnych dla towarów i zdecydować, czy wykonywać te czynności we własnym okresie, czy outsourcingować ${ }^{25}$.

W procesie obsługi zwrotów ważnym etapem jest określenie przyczyny zwrotu i na jej podstawie określenie dla niej drogi powrotnej towarów. Taki zabieg pozwala na minimalizację kosztów obsługi logistycznej zwrotów. Zamiast wysyłać od razu wszystkie produkty w górę łańcucha dostaw należy w punkcie przyjmowania zwrotów sprawdzić produkt pod względem jakości i ustalić rodzaj usterki i na tej podstawie podejmować dalsze decyzje co do produktu. Produkty dobre, nieuszkodzone mogą wrócić do sprzedaży, uszkodzone należy naprawić i zwrócić klientowi lub wprowadzić do wtórnej sprzedaży, produkty, których nie można naprawić lub ponownie sprzedać, trzeba oddać na złom lub do recyklingu.

Osobnym problemem jest gospodarka opakowaniami, które są kolejnym elementem wchodzącym w skład pakietu oferowanego w produkcie logistycznym.

Opakowania są tym ogniwem, które łączy producenta poprzez handel z ostatnim odbiorcą produktu - konsumentem. W logistyce jest ono metodą ochrony i zabezpieczenia ładunku w czasie transportu oraz pełni funkcję manipulacyjną ułatwiającą prowadzenie ładunku i obniżającą koszty transportu, poprzez zmniejszanie masy opakowania ${ }^{26}$.

Podstawowymi czynnikami wpływającymi na jakość opakowań i składającymi się na proces ich powstawania są ${ }^{27}$ :

- projektowanie i opracowywanie wzorów opakowań,

- opracowywanie założeń i technologii produkcji,

- wybór i zakup surowców i tworzyw opakowaniowych,

- zastosowanie odpowiedniej techniki produkcji,

- kontrola jakości opakowań.

${ }^{24}$ Ustawa z dnia 27 lipca 2002 r. o szczególnych warunkach sprzedaży konsumenckiej oraz o zmianie Kodeksu cywilnego, http://www.mg.gov.pl/NR/rdonlyres/02CDFF11-4217-4078A37A-240588C1EDBF/16575/Ust_o_szczegol_warunkach_sprzed_konsumenc_tekst_je.pdf (dostęp 14.09.2011).

${ }^{25}$ K. Rutkowski, Logistyka dystrybucji..., s. 229.

${ }^{26}$ E. Gołembska (red.), Kompendium wiedzy..., s. 94.

${ }^{27}$ Ibidem, s. 97. 
Kolejnym etapem jest wykorzystanie opakowania do zapakowania i oznakowania towaru i dostarczenie $\mathrm{w}$ nim produktu do konsumenta, a na końcu mamy do czynienia z zagospodarowaniem zużytego opakowania.

Przepisy z zakresu gospodarki opakowaniami i odpadami opakowaniowymi, będące transpozycją postanowień unijnej dyrektywy „opakowaniowej”, obowiązują w Polsce od 2005 r.

Już w 2007 r. Polska była zobowiązana do osiągnięcia poziomu odzysku $50 \%$ i recyklingu $25 \%$ łącznej masy opakowań wprowadzanych na rynek krajowy wraz z wyrobami. Oznaczało to, że połowa opakowań wykorzystywanych w Polsce do pakowania produktów, po utracie swojej funkcjonalności, nie miała prawa trafić na składowiska. Wymogi w tym zakresie stale rosną, do roku 2014 Polska jest zobowiązana osiągnąc odzysk opakowań na poziomie $60 \%$, a recykling na poziomie minimum 55\%.

Bezpośrednią odpowiedzialność za realizację tych zobowiązań ponoszą przedsiębiorcy wprowadzający na rynek produkty w opakowaniach. W myśl zasady „zanieczyszczający płaci” są oni zobowiązani zadbać o swój produkt w całym cyklu jego życia. Co za tym idzie, powinni również zapewnić wymagany prawem poziom odzysku i recyklingu odpadów, które powstaną z opakowań ich produktów.

Zobowiązania te zostały w Polsce wprowadzone na mocy dwóch ustaw, będących implementacją postanowień Dyrektywy Parlamentu i Rady Europejskiej nr 94/62/WE z dnia 20 grudnia 1994 r. w sprawie opakowań i odpadów opakowaniowych:

- Ustawa z 11 maja 2001 r. o obowiązkach przedsiębiorców w zakresie gospodarowania niektórymi odpadami oraz o opłacie produktowej i opłacie depozytowej (tekst jednolity Dz.U. 2007, nr 90, poz. 607 z późniejszymi zmianami; dalej: ustawa o opłacie produktowej);

- Ustawa z 11 maja 2001 r. o opakowaniach i odpadach opakowaniowych (Dz.U. 2001, nr 63, poz. 638 z późniejszymi zmianami).

Obie ustawy weszły w życie 1 stycznia 2002 r. Swoim zakresem dotyczącym obowiązku odzysku i recyklingu opakowań objęły następujące grupy przedsiębiorców:

- wytwórców produktów w opakowaniach;

- importerów oraz firmy dokonujące wewnątrzwspólnotowego nabycia towaru (WNT - z wykluczeniem importu lub WNT w celach eksportu lub wewnątrzwspólnotowej dostawy towarów - WDT);

- przedsiębiorców prowadzących jednostkę handlu detalicznego o powierzchni handlowej powyżej $500 \mathrm{~m}^{2}$ sprzedających produkty tam pakowane;

- przedsiębiorców prowadzących więcej niż jedną jednostkę handlu detalicznego o łącznej powierzchni handlowej powyżej $5000 \mathrm{~m}^{2}$, sprzedających produkty tam pakowane; 
- przedsiębiorców, którzy pakują produkty wytworzone przez innego przedsiębiorcę i wprowadzają je na rynek krajowy;

- przedsiębiorców, nie będących wytwórcami produktu, którzy zlecili wytworzenie tego produktu oraz których oznaczenie zostało umieszczone na produkcie lub opakowaniu ${ }^{28}$.

Firmy te są zobowiązane do zapewnienia określonego prawem poziomu odzysku i recyklingu odpadów powstałych z opakowań produktów wprowadzanych na polski rynek.

Opakowania, z których przedsiębiorcy powinni się rozliczać, obejmują te wykonane $z$ tworzyw sztucznych, aluminium, stali, papieru i tektury, szkła gospodarczego oraz drewna. Przepisom ustawy podlegają także opakowania wielomateriałowe, obciążające obowiązkiem odzysku i recyklingu w zakresie przeważającej grupy materiałowej (np. kartony do pakowania płynnej żywności, w ok. $70 \%$ składające się z papieru, rozliczane będą jako opakowania z papieru i tektury).

Rozliczenie wprowadzanych na rynek opakowań następuje na koniec roku kalendarzowego. W przypadku nieosiągnięcia określonych prawem poziomów odzysku i recyklingu przedsiębiorcy są zobowiązani do uiszczenia do urzędu marszałkowskiego opłaty produktowej. Jest to najbardziej kosztowny sposób realizacji obowiązków. Opłata ta ma charakter sankcyjny, mający zmusić przedsiębiorców do poszukiwania innych, bardziej ekologicznych sposobów realizacji ustawowych obowiązków.

W celu uniknięcia wysokich kosztów przedsiębiorcy mogą zaangażować się w odzysk i recykling. Mają dwie możliwości: samodzielną realizację obowiązków lub przekazanie ich organizacji odzysku. Decydując się na tę pierwszą opcję, należy dokonać fizycznego przetworzenia odpadów lub zorganizować sieć selektywnego ich zbierania, w celu zapewnienia recyklingu.

Decydując się na samodzielną realizację ustawowych obowiązków, nie można zapominać o szczegółowej weryfikacji firm recyklingowych pod kątem wymogów prawnych. Dokumenty potwierdzające odzysk i recykling (DPO i DPR) wystawione przez firmy nie posiadające do tego stosownych uprawnień będą nieważne w świetle prawa. W ten sposób realizacja obowiązku odzysku i recyklingu będzie nieskuteczna, co spowoduje konieczność uiszczenia opłaty produktowej do urzędu marszałkowskiego.

Prostym sposobem uniknięcia tych problemów jest przekazanie ciążących na przedsiębiorcach obowiązków organizacji odzysku. Firma ta na mocy ustawy

\footnotetext{
${ }^{28} \mathrm{https}: /$ www.google.pl/url?sa=t\&rct=j\&q=\&esrc=s\&source=web\&cd=2\&ved=0CDQQFjAB \&url=http\%3A\%2F\%2Fisap.sejm.gov.pl\%2FDownload\%3Bjsessionid\%3D4D5FE104FE835ACE FEC0CED3728174F3\%3Fid\%3DWDU20070900607\%26type\%3D1\&ei=dXADUqblOYO1O_rZg egI\&usg=AFQjCNHGIQVx9dcJMyjGaDfGoH6eBT-_TA\&sig2=cnGOvz88r-716v26pMzU9g\&bvm =bv.50500085,d.ZWU (dostęp 08.08.2013).
} 
jest podmiotem ściśle wyspecjalizowanym w zakresie realizacji obowiązku odzysku i recyklingu. To organizacja odzysku musi zadbać o monitorowanie działania firm recyklingowych, bo to ona ponosi odpowiedzialność za wszelkie nieprawidłowości w tym zakresie. Nawiązując współpracę z organizacją odzysku, przedsiębiorca unika zarówno ryzyka związanego z niewłaściwym gospodarowaniem odpadami, jak i obowiązku sprawozdawczego, który zostaje przeniesiony na organizację odzysku. Rozliczenie za pośrednictwem organizacji odzysku jest najpopularniejszym sposobem wywiązywania się z postanowień ustawy o opłacie produktowej.

\section{Zakończenie}

Przedstawione dane statystyczne i wyniki badań potwierdzają dynamiczny rozwój polskiego rynku e-commerce. Wpływ na to mają przede wszystkim użytkownicy Internetu, którzy dokonują zakupów na wirtualnych rynkach, jak również e-sklepy, dbając o jak najwyższy poziom obsługi. Powszechny dostęp do sieci powoduje przeobrażenia w społeczeństwie, które staje się społeczeństwem mobilnym. Współcześnie, by skorzystać z Internetu, nie jesteśmy już skazani wyłącznie na komputer, taką sposobność dają nam tablety, palmtopy czy nawet telefony komórkowe. Dzięki takim rozwiązaniom możemy korzystać z dobrodziejstw Internetu w każdym miejscu, o każdej porze. Klienci nie są zależni już od godzin otwarcia sklepów oraz nie muszą wychodzić z domu - kupują w sieci ze względu na wygodę.

\section{Literatura}

Barcik R., Logistyka dystrybucji, Wydawnictwo ATH, Bielsko-Biała 2005.

Bickerton P., Bickerton M., Pardesi U., Marketing w Internecie, Gdańskie Wydawnictwo Psychologiczne, Gdańsk 2006.

Gołembska E. (red), Kompendium wiedzy o logistyce, Wydawnictwo Naukowe PWN, Warszawa 2007.

Jadczak A., eCommerce 2012, Internet Standard, http://www.internetstandard.pl/news/event/15/ 946567/1B8885129EFD40F193C576EBEC22236C.

Maciejowski T., Firma w Internecie, Oficyna Ekonomiczna, Kraków 2004.

Rutkowski K., Logistyka dystrybucji. Specyfika. Tendencje rozwojowe. Dobre praktyki, SGH, Warszawa 2005.

Sadowski A., Zarys rozwoju logistyki zwrotnej, „Logistyka” 2009, nr 5.

Shapiro C., Varian H. R., Potęga informacji. Strategiczny przewodnik po gospodarce sieciowej, Harvard Business School Press 2007.

Świerczyńska-Kaczor U., Kossecki P., Wirtu@alny rynek. Inwestorzy. Przedsiębiorstwa. Klienci, Wydawnictwo Uniwersytetu Humanistyczno- Przyrodniczego Jana Kochanowskiego, Kielce 2008. 
Ustawa z 2 marca 2000 r. o ochronie niektórych praw konsumentów oraz o odpowiedzialności za szkodę wyrządzoną przez produkt niebezpieczny, http://isip.sejm.gov.pl/servlet/Search? todo=file\&id=WDU20000220271\&type $=3 \&$ name $=$ D20000271Lj.pdf.

Ustawa z dnia 27 lipca 2002 r. o szczególnych warunkach sprzedaży konsumenckiej oraz o zmianie Kodeksu cywilnego, http://www.mg.gov.pl/NR/rdonlyres/02CDFF11-4217-4078A37A-240588C1EDBF/16575/Ust_o_szczegol_warunkach_sprzed_konsumenc_tekst_je.pdf.

Wielki J., Elektroniczny marketing poprzez Internet, Wydawnictwo Naukowe PWN, WarszawaWrocław 2000.

http://www.pmrpublications.com/product/Handel-internetowy-w-Polsce-2012.

\section{Streszczenie}

Handel elektroniczny zawdzięcza swoją rosnącą popularność logistyce, dającej możliwość przemieszczania towarów na bardzo dalekie odległości. W referacie przedstawiono charakterystykę produktów dostępnych w Internecie oraz dokonano ich systematyki. Przedstawiono wyniki badań własnych odnośnie oceny asortymentu dostępnego w polskich sklepach elektronicznych oraz przepływu produktów w kanałach dystrybucji. Szczególna uwagę zwrócono na działania z zakresu logistyki zwrotnej, jako źródła tworzenia przewagi konkurencyjnej.

\section{Summary}

\section{EVALUATION OF LOGISTICS CUSTOMER SERVICE AND E-COMMERCE ASSORTMENT OFFER}

Electronic commerce owes its growing popularity logistics, allowing them to move goods very long distances. The paper presents the characteristics of the products available on the Internet and made their taxonomy. The paper presents results of research on evaluation range available in Polish electronic stores and the flow of products in the distribution channels. Particular attention was paid to activities in the field of reverse logistics as a source to create a competitive advantage. 